\title{
PERANCANGAN KONSEP IDEAL DESA WISATA DI DESA CIBINUANG KABUPATEN KUNINGAN
}

\author{
Jerry Dounald Rahajaan ${ }^{1}$, Erik Kurniadi ${ }^{2}$, Fahmi Yusuf ${ }^{3}$, Erlan Darmawan ${ }^{4}$ dan Resma \\ Mega Herawati ${ }^{5}$ \\ Program Studi Desain Komunikasi Visual $\mathrm{S}^{15}$, Sistem Informasi $\mathrm{S} 1^{2,3}$, Teknik Informatika $\mathrm{S} 1^{4}$, \\ Fakultas Ilmu Komputer, Universitas Kuningan, Indonesia \\ E-mail : jerry@uniku.ac.id
}

\begin{abstract}
Cibinuang Village is an area located in Kuningan District, Kuningan Regency. Cibinuang Village has many and varied natural resources. In the process of development activities Cibinuang tourism village has not fully used the detailed concept of tourism. The development of the concept of tourism in the Village of Cibinuang did not escape the existence of adequate natural resources and quality human resources. The availability of natural resources and their use in Cibinuang Village, even if simple and limited, will be able to improve the quality of the village and be a source of increased human resources for the community. In terms of improving the economy, knowledge and attractiveness of tourism. Efforts to design the concept of a tourist village, in improving the ability of rural communities in the field of tourism required a whole design concept to make it happen. It is understood together that one of the concrete manifestations of Higher Education gait besides education and research is Community Service and Service activities, this is in accordance with what is mandated in Law No. 20 of 2003 concerning National Education System article 24 (2) which states; "Universities have the autonomy to manage their own institutions as centers for the administration of higher education, scientific research, and community service." As a concrete step Faculty of Computer Science, Kuningan University with the core of Visual Communication Design, trying to respond to the needs of the community (Cibinuang Village) of the importance of developing Tourism Villages by doing Community Service with the title of the activity "The Concept of Designing Tourism Villages in Cibinuang Area Kuningan District of West Java Province" . Referring to the background of existing problems, problem solving is needed for the purpose of this activity are: Designing the concept of village tourism design for the people of Cibinuang Village, Kuningan Regency, to utilize natural resources in the area, which include: Hot Springs, Campgrounds, Sacred / Ancient Tombs. Creating a Tourism Village Study Plan for Cibinuang Village Community, Kuningan District to realize the Village program.
\end{abstract}

Keywords: Tourism Village, Natural Resources, Cibinuang, Village Program

\begin{abstract}
Abstrak
Desa Cibinuang merupakan salah satu daerah yang terletak di Kecamatan Kuningan Kabupaten Kuningan. Desa Cibinuang memiliki sumberdaya alam yang banyak dan berfariasi. Dalam proses kegiatan pengembangan Desa wisata Cibinuang belum sepenuhnya menggunakan konsep wisata yang terinci. Perkembangan konsep pariwisata di Desa Cibinuang tidak luput dari adanya sumberdaya alam yang memadai dan sumber daya manusia yang berkualitas. Ketersediaan sumber alam dan pemanfaatannya di Desa Cibinuang, sekalipun sederhana dan terbatas, akan dapat meningkatkan kualitas desa serta menjadi sumber peningkatan SDM bagi masyarakat. Dalam hal peningkatan ekonomi, pengetahuan, dan daya tarik pariwisata. Upaya perancangan konsep desa wisata, dalam peningkatan kemampuan masyarakat desa dalam bidang pariwisata diperlukan suatu konsep desain yang utuh untuk mewujudkannya. Dipahami bersama bahwa salah satu wujud nyata kiprah Perguruan Tinggi selain pendidikan dan penelitian adalah kegiatan Pengabdian dan Pelayanan kepada Masyarakat, hal ini sesuai dengan
\end{abstract}


apa yang diamanatkan dalam UU No. 20 Tahun 2003 tentang Sistem Pendidikan Nasional pasal 24 (2) yang menyatakan; "Perguruan tinggi memiliki otonomi untuk mengelola sendiri lembaganya sebagai pusat penyelenggaraan pendidikan tinggi, penelitian ilmiah, dan pengabdian kepada masyarakat". Sebagai langkah kongkrit Fakultas Ilmu Komputer Universitas Kuningan dengan core Desain Komunikasi Visual, mencoba untuk merespon kebutuhan masyarakat (Desa Cibinuang) akan pentingnya pengembangan Desa Wisata dengan melakukan Pengabdian Kepada Masyarakat dengan judul kegiatan "Konsep Perancangan Desa Wisata Di Daerah Cibinuang Kabupaten Kuningan Provinsi Jawa Barat”. Mengacu pada latar belakang permasalahan yang ada maka dibutuhkan pemecahan masalah untuk tujuan kegiatan ini adalah: Merancang konsep Desain desa wisata bagi Masyarakat Desa Cibinuang, Kabupaten Kuningan, untuk memanfaatkan sumber daya alam yang ada di daerahnya, yaitu meliputi: Sumber Air Panas, Bumi Perkemahan, Makam Keramat/Kuno. Membuat StudyPlan Desa Wisata bagi Masyarakat Desa Cibinuang, Kabupaten Kuningan untuk mewujudkan program Desa.

Kata Kunci : Desa Wisata, Sumber Daya Alam, Cibinuang, Program Desa

\section{PENDAHULUAN}

Desa Wisata saat ini berkembang sangat cepat dan pesat. Pariwisata saat ini sudah menjai salasatu sumber defisa bagi daerah/desa. Konsep Desa Wisata dari waktu ke waktu meningkat dengan cepat. Hal ini mengakibatkan banyak perubahan dalam pola kehidupan masyarakat sehari-hari. Perkembangan daerah Pariwisata yang begitu cepat dan pesat memberikan dampak positif dan negatif. Pengertian pariwisata menurut A.J Burkat dalam Damanik (2006),parwisata adalah perpindahan orang untuk sementara dan dalam jangka waktu pendek ke tujuan-tujuan diluar tempat dimana mereka biasa hidup dan bekerja dan juga kegiatan-kegiatan mereka selama tinggal di suatu tempat tujuan.

Desa wisata merupakan pengembangan suatu wilayah desa yang pada dasarnya tidak merubah apa yang sudah ada akan tetapi lebih cenderung kepada pengembangan potensi desa yang ada dengan melakukan pemanfaatan kemampuan unsur- unsur yang ada di dalam desa yang berfungsi sebagai atribut produk wisata dalam skala yang kecil menjadi rangkaian aktivitas atau kegiatan pariwisata dan mampu menyediakan serta memenuhi serangkaian kebutuhan perjalanan wisata baik dari aspek daya tarik maupun sebagai fasilitas pendukung (A.J, Muljadi, 2012). Untuk mengetahui penerimaan masyarakat terhadap kegiatan pengembangan desa wisata : 1) Tidak bertentangan dengan adat istiadat budaya masyarakat setempat; 2) Pengembangan fisik yang di ajukan untuk meningkatkan kualitas llingkungan desa; 3) memperhatikan unsur kelokalan dan keaslian; 4) Memberdayakan masyarakat desa; 5) Memperhatikan daya dukung dan daya tampung berwawasan lingkungan (Antara Made, 2015).

Dampak positif dari perkembangan daerah Pariwisata diantaranya adalah: Kemajuan ekonomi di Masyarakat; Perkembangan informasi yang pesat dan luas; Pengembangan sumber daya alam dengan baik; Pengembangan sumber daya manusia yang terukur; Pengembangan Pengetahuan bagi Masyarakat; Sarana hiburan; Media promosi; Penyebaran Budaya; Sumber penghasilan masyarakat; dan masih banyak lagi manfaat dari adanya Desa Wisata dalam kehidupan masyarakat kesehariannya.

Selain memberikan dampak positif dalam kehiudpan sehari-hari, Desa Wisata juga memiliki dampak negatif. Dampak negatif dari perkembangan Desa Wisata diantaranya adalah: Terjadinya kulturasi budaya di Masyarakat; Perubahan pola hidup di 
Masyarakat; Kepadatan penduduk; dan masih banyak lagi dampak negatif dari adanya Desa Wisata dalam kehidupan masyarakat kesehariannya.

Konsep Desa Wisata tidak mungkin terwujud tanpa adanya sumberdaya manusia yang berkualitas. Peningkatan SDM dan pemanfaatannya di Desa Wisata, sekalipun memerlukan waktu pembinaan yang lama dan bertahap, akan dapat meningkatkan pengetahuan masyarakat dalam hal peningkatan efektifitas, efisiensi, kerja dalam pola kehidupan Masyarakat setempat. Ukuran untuk menentukan peran serta pihak dalam upaya mengembangkan suatu daya tarik wisata secara umum mengacu kepada UndangUndang No. 10 Tahun 2009 tentang kepariwisataan. Materi pokok yang dijadikan acuan adalah pasal 23 Undang-Undang No. 10 Tahun 2009 pada ayat 1 tentang bagaimana kewajiban pemerintah dan pemerintah daerah. Pada pasal 23 ayat 1 ini ditegaskan apa yang menjadi kewajiban pemerintah daerah. Ukuran kewajiban yang menjadi tanggung jawab pemerintah daerah itu yang menjadi tolak ukur seberapa jauh peran serta pihak pemerintah daerah dalam mengembangkan daya tarik wisata. Perubahan paradigma pembangunan yang pada saat ini telah dicanangkan oleh pemerintah yang menjadikan desa sebagai subjek dan bukan lagi sebagai objek dalam pembangunan bukan suatu perkara mudah dalam pelaksanaannya, banyak pekerjaan rumah yang harus segera diselesaikan baik yang berkaitan dengan pembangunan secara fisik maupun non fisik salah satunya melalui pariwisata (Endra Suseno, 2018).

Upaya peningkatan kemampuan masyarakat desa dalam bidang pariwisata diperlukan peran serta dunia pendidikan tinggi untuk mewujudkannya. Dipahami bersama bahwa salah satu wujud nyata kiprah Perguruan Tinggi selain pendidikan dan penelitian adalah kegiatan Pengabdian dan Pelayanan kepada Masyarakat, hal ini sesuai dengan apa yang diamanatkan dalam UU No. 20 Tahun 2003 tentang Sistem Pendidikan Nasional pasal 24 (2) yang menyatakan; "Perguruan tinggi memiliki otonomi untuk mengelola sendiri lembaganya sebagai pusat penyelenggaraan pendidikan tinggi, penelitian ilmiah, dan pengabdian kepada masyarakat". Sebagai langkah kongkrit Fakultas Ilmu Komputer Universitas Kuningan dengan core DesainKomunikasi Visual, mencoba untuk merespon kebutuhan masyarakat (masyarakat Desa Cibinuang) akan pentingnya konsep dan pemetaan desa wisata dengan melakukan Pengabdian Kepada Masyarakat dengan judul kegiatan "Konsep Perancangan Desa Wisata Di Daerah Cibinuang Kabupaten Kuningan Provinsi Jawa Barat".

Kuningan merupakan salah satu kabupaten di Jawa Barat yang memiliki berbagai obyek wisata. Selain wisata alam banyak pula wisata lainnya seperti wisata air modern yang menyediakan waterboom, wisata sejarah, wisata religius dan wisata kuliner (Erik Kurniadi dan Heru Budianto, 2019). Berdasarkan analisis situasi dan kajian data di atas, dapat disimpulkan bahwa Masyarakat Desa Cibinuang, Kabupaten Kuningan mengalami permasalahan dalam memanfaatkan Sumber daya alam terutama dalam Konsep Perancangan Desa Wisata. Permasalahan tersebut disebabkan oleh berbagai faktor, diantaranya yang sangat penting adalah konsep dan stadyplan dalam pengembangan konsep desa wisata yang masih memerlukan pembinaan serta pemikiran yang matang 
Empowerment : Jurnal Pengabdian Masyarakat, e-ISSN 2598-2052

Vol. 03 Nomor 02.2020. 89-97.

\section{METODE PELAKSANAAN}

Dalam kegiatan pengabdian kepada masyarakat ini, adapun kerangka pemecahan masalah sebagai beirkut :

\section{Masalah Mitra:}

1. Tidak ada konsep desa wisata bagi Masyarakat Desa Cibinuang, Kabupaten Kuningan dalam program kerja desa

2. Tidak ada StudyPlan Desa Wisata di pengurus Desa Cibinuang, Kabupaten Kuningan untuk mewujudkan program desa wisata

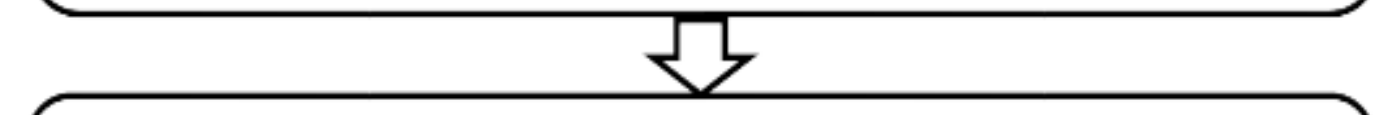

\section{Pemecahan Masalah:}

Dengan membantu dalam penyusunan konsep dan studyplan desa wisata melalui penyusunan program kerja pada pengurus Desa Cibinuang Kec. / Kab. Kuningan dalam kegiatan pengabdian pada masyarakat akan memberikan dampak positif terhadap kinerja program kerja desa

\section{Program Kemitraan Masyarakat:}

1. Melakukan sosialisasi program desa wisata dalam Pembangunan desa.

2. Membantu pengurus desa terkait pemataan wilayah dalam programkerja desa wisata.

3. Memberikan pelatihan pada pengurus desa dalam menentukan program kerja yang fisibel untuk pelaksanaan desa wisata.

4. Memberikan pemahaman dan pelatihan terkait program kerjadesa wisata.

\section{Monitoring dan Evaluasi:}

Proses monitoring dilakukan setelah kegiatan penyuluhan dan pelatihan selesai diselengarakan dengan melihat apakah semua kegiatan sudah berjalan sesuai dengan program yang direncanakan. Proses evaluasi dilakukan dengan tujuan untuk mengetahui seberapa besar tingkat keberhasilan Program Kemitraan Masyarakat ini mampu memberikan perubahan terhadap kondisi mitra dalam menyelesaikan permasalahan yang

\section{Luaran:}

1. Peningkatan pemahaman dan kesadaran pengurus desa terhadap kapasitasnya dalam membangun desa melalui program kerja desa wisata

2. Penyuluhan dan pelatihan yang diselengarakan akan memberikan dampak yang baik terhadap peningkatan kualitas program kerja Desa Cibinuang.

3. Materi pelatihan konsep desain dan penyusunan program kerjadesa wisata.

4. Target lainnya yang diharapkan bagi tim pengabdian kepada masyarakat ini adalah sebagai bentuk pelaksanaan Thi Dharma perguruan tinggi dan sebagai rasa bentuk

Gambar 1. Alur Kerangka Pemecahan Masalah 
Berdasarkan permasalahan yang ditemukan dan dirumuskan, maka kerangka pemecahan masalah yang dilakukan melalui kegiatan Pengabdian Pada Masyarakat ini adalah pelatihan terkait konsep desain dan pembuatan program kerja Desa Cibinuang Kecamatan / Kabupaten Kuningan terkait desa wisata. Metode dalam kegiatan pengabdian masyarakat ini adalah partisipasi aktif dengan tahapan kegiatan sebagai berikut:

1. Diskusi terkait kerangka konsep desa wisata.

2. Membantu secara konsep pembuatan program kerja desa wisata.

3. Pendampingan dalam membuat konsep desain serta pemetaan wilayah desa wisata..

Kerangka pemecahan masalah yang telah dirumuskan kemudian direalisasikan dalam beberapa tahapan kegiatan sebagai upaya merealisasikan pemecahan permasalahan tersebut. Adapun tahapan kegiatan yang dilakukan dalam kegiatan pengabdian kepada masyarakat ini adalah sebagai berikut:

1. Tahap Persiapan

Observasi awal dan evaluasi lapangan dilakukan pada wilayah daerah desa Cibinuang, dengan cara melakukan pengamatan dan analisis terhadap data wilayah yang dimiliki. Pemetaan tersebut meliputi wilayah air panas, bumi perkemahan, makam kuno, terkait program kerja desa. Berdasarkan hasil observasi diperoleh informasi bahwa wilayah yang tergabung dalam wilayah desa Cibinuang dalam membuat program kerja desa wisata. Hal tersebut mengakibatkan program kerja yang dibuat menjadi sinerji dengan kebutuhan. Konsep desa wisata dalam program kerja bertujuan untuk meningkatkan produktivitas dan kesejahteraan masyarakat desa Cibinuang, serta meningkatkan sumberdaya alam yang di miliki oleh masyarakat di desa Cibinuang.

2. Tahap Pelaksanaan

Berdasarkan data yang diperoleh pada saat observasi tersebut, maka tim pengabdian kepada masyarakat menyelenggarakan diskusi dan pelatihan penyusunan program kerja dan proposal kegiatan untuk pemberdayaan masyarakat terkait program desa wisata di Desa Cibinuang Kec. / Kab. Kuningan. Program kerja Pemerintah Desa Cibinuang terkait kegiatan desa wisata disusun sesuai dengan jadwal pelaksanaan kegiatan pada Tabel 4.1 di atas. Pada umumnya Pemerintah Desa Cibinuang sangat antusias dengan konsep desain yangditawarkan ini, ditunjukkan dengan diundangnya kami dalam proses penyusunan program kerja desa wisata.

Diskusi dan dialog tentang desa wisata terkait pemberdayaan masyarakat dan peningkatanekonomis di Desa Cibinuang Kec. / Kab. Kuningan diisi dengan pemaparan materi yang sesuai dengan tema. Materi-materi yang disampaikan kepada desa meliputi: peran pemuda dalam pembangunan desa, mekanisme penyusunan program kerja dan pemetaan wilayah wisata. Lokasi yang digunakan untuk kegiatan pelatihan adalah di balai desa Desa Cibinuang Kec. / Kab. Kuningan.

Pelatihan pembuatan program kerja dan konsep desaindesa wisata dibagi menjadi tiga kegiatan, yaitu ceramah dan tanya jawab tentang konsep desa wisata, memberikan pelatihan teknis penyusunan program kerja dan pemetaan wilayah wisata, dan pendampingan dalam membuat program kerja dan konsep desain. Pada akhir sesi diadakan tanya jawab dan sharing dengan peserta /pengurus desa mengenai 
kesulitan-kesulitan dan pengalaman yang pernah dialami dalam hal penyusunan program kerja dan konsep desain. Permasalahan-permasalahan tersebut dikaji dan dibimbing oleh tim pengabdi untuk dicari solusinya. Dalam Pelatihan teknis penyusunan program kerja dan pemetaan wilayah wisata, para peserta dibagi menjadi beberapa kelompok sesuai dengan struktur wilayah masing-masing. Kemudian tim pengabdi meminta kelompok-kelompok peserta untuk mencari dan menemukan ide kegiatan yang akan dibuatkan menjadi program kerja berdsarkan situasi dan potensi Desa Cibinuang dan setiap program yang telah terkoordinir disusun guna implementasi program kerja yang akan diajukan kepada Pengurus Desa Cibinuang khususnya yang berhubungan dengan program desa wisata.

Dalam tahap diskusi ini dilakukan metode elaborasi atropologi kognitif.. Elaborasi Antropologi kognitif adalah manifestasi dalam bentuk lisan, visual, tulisan, dan aturan yang ada di masyarakat dalam bentuk fenomena budaya, agama, masyarakat, dan politik di masyarakat Nusantara (Jerry Dounald Rahajaan dan Sigit Setya Kusuma, 2018).

Pelatihan penyusunan program kerja dan pemetaan wilayah wisata untuk Desa Cibinuang Kec. / Kab. Kuningan diakhiri dengan sesi ketiga, yaitu pendampingan dalam membuat program kerja dan strategi konsep desain. Metode ini sebagai kelanjutan dari metode kedua, dimana kelompok peserta menghasilkan program kerja dan konsep desain. Proposal yang terpilih tersebut disempurnakan dan dilengkapi sehingga hasil akhirnya adalah proposal yang siap untuk diajukan ke pemerintah desa ataupun ke sponsor untuk memperoleh dana.

Untuk melaksanakan kegiatan tersebut digunakan beberapa metode pelatihan, yaitu:

1. Ceramah, tanya jawab

Metode ceramah digunakan untuk menyampaikan penjelasan kepada peserta tentang materi terkait kapasitas dan peran desa wisata guna pengembengan desa kedepannya. Pada sesi ini juga disampaikan contoh program kerja berdasarkan kebutuhan dan potensi desa, proposal yang sudah jadi, untuk memperjelas gambaran format program kerja dan proposal kegiatan yang akan dibuat oleh desa

2. Diskusi

Diskusi dilakukan untuk menggali persoalan-persoalan yang berhubungan dengan desa wisata, pembuatan program kerja dan konsep desain, serta memberikan pemahaman teknis pembuatan program kerja dan konsep desa wisata.

3. Pendampingan

Pendampingan ini bertujuan memberikan pengarahan pada saat pembuatan program kerja dan pembuatan konsep desain desa wisata.

\section{HASIL DAN PEMBAHASAN}

Kegiatan pengabdian kepada masyarakat dilaksanakan sesuai dengan rencana yang telah ditetapkan. Peserta juga mengikuti kegiatan hingga selesai. Pengurus desa terlihat antusias dan menyenangi pemaparan materi (konsep) yang disampaikan oleh tim Pengabdian Pada Masyarakat. Beberapa peserta mengajukan pertanyaan terkait materi/konsep dan permasalahan- permasalahan yang muncul di dalam upaya melaksanakan kegiatan program kerja. Antusiasme desa terhadap tema dan materi yang 
disampaikan juga terlihat dari diterimanya usulan strategi konsep desa wisata yang ditawarka sebagai struktur konsep awal. Hal ini menunjukkan ketertarikan desa terhadap materi yang disampaikan. Peserta juga mengikuti keseluruhan kegiatan, baik sesi pertama, kedua, dan terakhir dengan sangat antusias.

Tema PPM yang dipilih oleh Tim pengabdi, yaitu Konsep Perancangan Desa Wisata Di Daerah Cibinuang Kabupaten Kuningan Provinsi Jawa Barat, berdasarkan kebutuhan desa yang dicanangkandalamrencana program kerja desa. Mengingat pentingnya konsep dan strategi programkerja dalam mengembangkan dan memajukan desanya, maka penmerintah desa wajib mengumpulkan ide-ide dan mengusahakan agar ide tersebut terlaksana dalam suatu struktur program kerja desa.

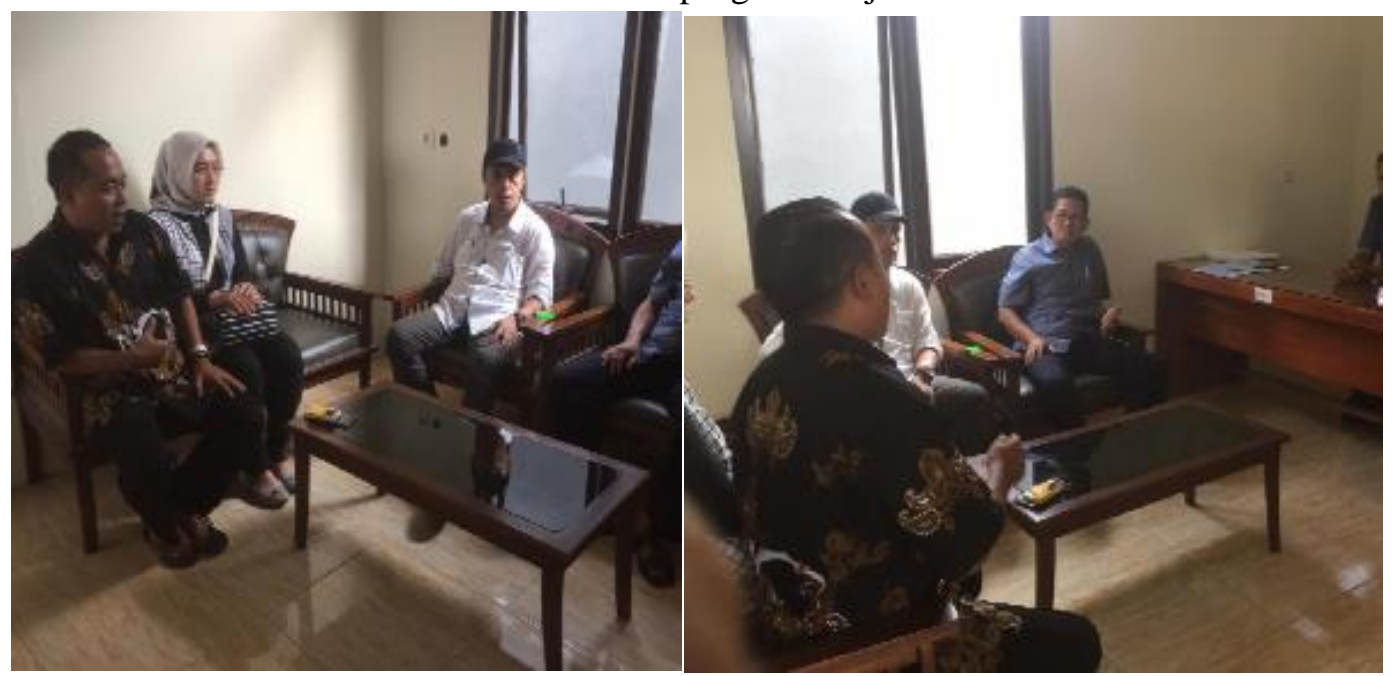

Gambar 1 Diskusi dengan Pemerintah Desa

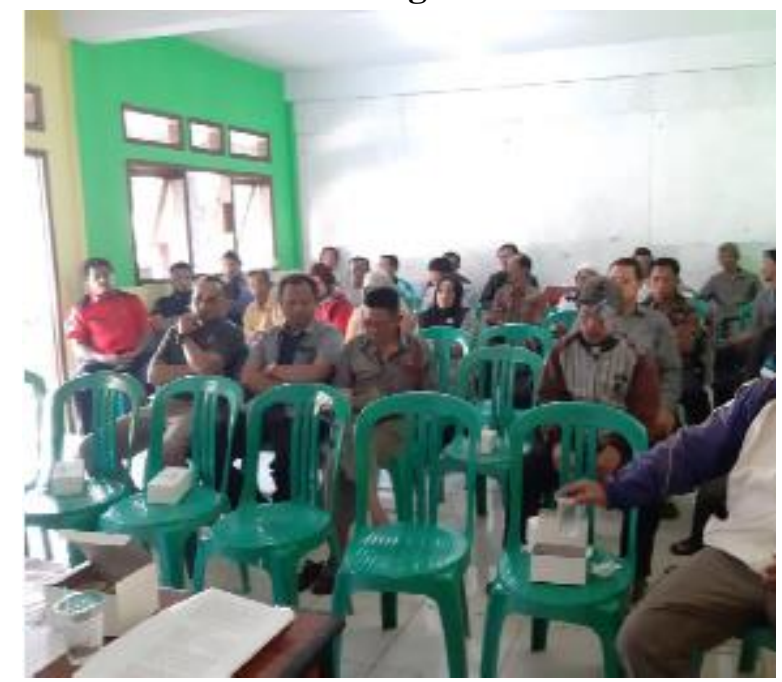

Gambar 2. Diskusi / penyuluhan dengan Perwakilan warga desa

Pelatihan dilaksanakan dalam tiga jenis kegiatan, sesuai dengan metode yang direncanakan sebelumnya. Kegiatan pertama yaitu diskusi dan tanya jawab tentang konsep besar desa wisata. Kegiatan ini berupaya memberikan pemahaman dan pengetahuan, dan gambaran mengenai pentingnya pemetaan wilayah dan bagaimana mengupayakan agar terbentuknya suatu program kerja yang sesuai, baik sosial maupun 
ekonomi. Kegiatan ini sekaligus mendorong semangat pengurus desa untuk tidak menyerah dan selalu kreatif menemukan ide baru. Sharing informasi dengan tim pengabdi memberikan efek yang positif karena permasalahan-permasalahan terkait program kerja yang muncul dapat dicari solusinya, terutama yang berkaitan dengan pendanaan kegiatan yang ingin diselenggarakan.

Setelah dilakukan sharing, dilanjutkan kegiatan pelatihan teknis penyusunan program kerja dan konsep desain. Peserta dibagi sesuai dengan bidang kerja di struktur organisasi pemerintah desa, masing-masing kelompok harus mendiskusikan ide yang memungkinkan untuk diangkat menjadi program kerja desa. Kemudian satu dari program kerja yang telah diusulkan tersebut dibuat rancangan konsep desain yang sesuai dengan data pemetaan wilayah wisata. Kegiatan pelatihan ini mengakomodasi ide-ide yang unik dan kreatif dari masing-masing bagian. Setiap peserta dalam kelompok juga memberikan masukan dan pertimbangan dari beberapa ide yang dirumuskan. Dengan demikian setiap anggota punya keleluasaan untuk berpikir kreatif dan menyampaikan pandangannya. Tim pengabdi membantu mengarahkan dan sharing dalam proses penyusunan draft program kerja oleh desa. Kegiatan terakhir yaitu pendampingan dalam pembuatan program kerja desa terkait desa wisata. Kegiatan ini menindaklanjuti draft konsep awal yang telah dihasilkan dari pemetaan wilayah wisata. Tim pengabdi bersama-sama dengan desa memilih salah satu dari draft yang telah dihasilkan dan disetujui bersama.

Pemilihan didasarkan pada pertimbangan waktu pelaksanaan program serta kemampuan desa untuk merealisasikan kegiatan yang direncanakan. Setelah masingmasing konsep terancang, maka penyusun program kerja dan konsep desain secara lengkap di buat. Tim pengabdi bertugas untuk memberikan masukan-masukan selama proses penyusunan program kerja dan konsep desain. Materi-materi yang disampaikan oleh tim PPM menjadi modal bagi desa untuk lebih kreatif dan memberikan kontribusi pada penyusunan program kerja dan konsep desain. Dalam perencaan ini juga dirancang media promosi yang tepat disesuaikan dengan perkembangan teknologi dan kebutuhan dari desa. Menurut Fahmi Yusuf (2016) promosi melalui internet merupakan salah satu bentuk penjualan masa kini. Tidak hanya bentuk penawaran barang dan jasa saja yang bisa didapatkan melalui internet akan tetapi proses transaksi secara online hingga pembayarannya dapat dilakukan tanpa harus dilakukan tatap muka antara produsen dan konsumen. Berdasarkan hasil pembahasan, dapat dikatakan bahwa kegiatan pelatihan terlaksana dengan baik dan memberikan manfaat bagi desa. Pemilihan materi dirasakan sesuai dan bermanfaat dalam rangka penyusunan programkerja dan konsep desain desa wisata dalam pembangunan desa dan pemberdayaan masyarakat serta menghasilkan peningkatan kualitas masyarakat dalam bidang ekonomi untuk pemberdayaan masyarakat pada desa Cibinuang.

\section{SIMPULAN}

Berdasarkan uraian tersebut di atas maka penulis disimpulkan beberapa hal berikut yaitu antara lain :

1. Kegiatan Pengabdian Pada Masyarakat berhasil memetakan wilayahwisata, konsep desain dan program kerja desa wisata di desa Cibinuang

2. Kegiatan telah berhasil memberikan kesadaran terhadap pengurus/pemerintah desa Cibinuang terkait pentingnya konsep desain dalam program kerja mereka. 
3. Kegiatan pelatihan berhasil mendorong pengurus ataupun pemerintah desa untuk menyusun dan menentukan program kerja yang mungkin untuk dilaksanakan.

4. Kegiatan pelatihan telah memberikan keterampilan membuat pemetaan wilayah dan konsep desain desa wisata

\section{SARAN}

Perlu diakomodasi ide-ide dari desa untuk melaksanakan kegiatan dalam rangka pemberdayaan masyarakat. Salah satunya dengan cara melakukan koordinasi dan sharing informasi secara rutin dan berkelanjutan. Rencana kegiatan yang telah dibuat, diharapkan dapat ditindaklanjuti sehingga kemanfaatannya benar-benar ada. Perlu diadakan kegiatan sejenis dengan tema dan permasalahan yang berbeda sehingga program kerja desa dapat lebih berkembang lagi

\section{UCAPAN TERIMA KASIH}

Penulis ucapkan terima kasih kepada semua pihak yang telah membantu terlaksananya kegiatan pengabdian kepada masyarakat ini, diantaranya adalah Rektor Universitas Kuningan, Ketua LPPM Universitas Kuningan, Dekan Fakultas Ilmu Komputer, seluruh jajaran perangkat Desa Cibinuang, warga Desa Cibinuang. Semoga dengan adanya kegiatan pengabdian kepada masyarakat ini dapat berjalan berkesinambungan dan diterima banyak pihak.

\section{DAFTAR PUSTAKA}

A.J Burkat dalam Damanik. 2006. Perencanaan Ekowisata.

A.J, Muljadi. 2012. Kepariwisataan dan Perjalanan. Jakarta: Raja Grafindo Persad Antara Made. 2015. Pengelolaan Pariwisata Berbasis Potensi Lokal. Pustaka Larasan

Kurniadi, Erik dan Budianto, Heru. 2018. Rancang Bangun Aplikasi Wisata Kabuoaten Kuningan Berbasis Android Mmenggunakan Metode Location Based Service (LBS). Vol 4 No 2.2018.

Rahajaan, Jerry Dounald dan Kusuma, Sigit Setya. 2018.The Meaning of Nutmeg and Clove North Maluku In Popular Culture. Balong International Journal of Design : DKV FKOM UNIKU. Vol 1 No 1.2018

Suseno, Endra. 2018. Pemodelan Arsitektur Enterprise Sistem Informasi Data Kependudukan Desa dengan Frameword Ttogaf 9.1 dan SOA. VOL 3 No 3.

Yusuf, Fahmi dan Maulana, Wisnu Ahmad. 2016. Rancang Bangun E-Commerce B2C Pada Toko Nurjani. Jejaring : MID3 FKOM UNIKU. Vol 1 No 2.2018

Undang-Undang Nomor 20 Tahun 2003 tentang Sistem Pendidikan Nasional.

Undang-Undang Nomor 10 Tahun 2009 tentang kepariwisataan

Undang-Undang Nomor 6 Tahun 2014 tentang Desa. 